\title{
Calphostin C-mediated translocation and integration of Bax into mitochondria induces cytochrome $c$ release before mitochondrial dysfunction
}

\author{
H Ikemoto ${ }^{1}$, E Tani ${ }^{\star,}{ }^{1}$ I Ozaki ${ }^{1}$, H Kitagawa ${ }^{1}$ and N Arita ${ }^{1}$ \\ ${ }^{1}$ Molecular Biology Research Laboratory, Department of Neurosurgery, Hyogo \\ College of Medicine, 1-1 Mukogawa-cho, Nishinomiya, Hyogo 663-8501, \\ Japan \\ * Corresponding author: E. Tani, Tel: 81-798-45-6458; Fax: 81-798-45-6457; E- \\ mail: ike-ns@hyo-med.ac.jp
}

Received 6.10.99; revised 21.12.99; accepted 15.2.00

Edited by JC Reed

\begin{abstract}
Calphostin C-mediated apoptosis in glioma cells was reported previously to be associated with down-regulation of $\mathrm{Bcl}-2$ and $\mathrm{Bcl}-\mathrm{x}_{\mathrm{L}}$. In this study, we report that $100 \mathrm{nM}$ calphostin $\mathrm{C}$ also induces translocation and integration of monomeric Bax into mitochondrial membrane, followed by cytochrome $c$ release into cytosol and subsequent decrease of mitochondrial inner membrane potential $(\Delta \Psi \mathrm{m})$ before activation of caspase-3. The integration of monomeric Bax was associated with acquirement of alkali-resistance. The translocated monomeric Bax was partly homodimerized after cytochrome $c$ release and decrease of $\Delta \Psi \mathrm{m}$. The translocation and homodimerization of Bax, cytochrome $c$ release, and decrease of $\Delta \Psi \mathrm{m}$ were not blocked by $100 \mu \mathrm{M}$ z-VAD.fmk, a pan-caspase inhibitor, but the homodimerization of Bax and decrease of $\Delta \Psi \mathrm{m}$ were inhibited by $10 \mu \mathrm{M}$ oligomycin, a mitochondrial $F_{0} F_{1}$-ATPase inhibitor. Therefore, it would be assumed that mitochondrial release of cytochrome cresults from translocation and integration of Bax and is independent of permeability transition of mitochondria and caspase activation, representing a critical step in calphostin C-induced cell death. Cell Death and Differentiation (2000) 7, 511-520.
\end{abstract}

Keywords: calphostin C; Bax; cytochrome $c$; mitochondria

Abbreviations: Ac-DEVD-CHO, acetyl-Asp-Glu-Val-Asp aldehyde; Ac-DEVD-MCA, acetyl-Asp-Glu-Val-Asp a(4-methyl-coumaryl-7-amide); DTT, dithiothreitol; $\Delta \Psi \mathrm{m}$, mitochondrial inner membrane potential; $\mathrm{DiOC}_{6}(3), 3,3^{\prime}$-dihexyloxacarbocyanine; EDTA, ethylenediaminetetraacetic acid; EGTA, ethylene-glycolbis( $\beta$-amino-ethylether) $\mathrm{N}, \mathrm{N}^{\prime}$-tetraacetic acid; HEPES, N-2-hydroxyethylpiperazine- $\mathrm{N}$-2-ethanesulfonic acid; $\mathrm{HM}$, heavy membrane; $\mathrm{LH}$, light membrane; $\mathrm{mCICCP}$, carbonyl cyanide m-chlorophenylhydrazone; NP-40, Nonidet P-40; PARP, poly(ADP-ribose) polymerase; PMSF, phenylmethylsulfonyl fluoride; PTPC, permeability transition pore complex; P1, low speed pellet; SDS, sodium dodecylsulfate; z-VAD.fmk, z-Val-Ala-Asn fluoromethylketone

\section{Introduction}

A large body of evidence supports the idea that the apoptotic features are mediated by the activation of several cytosolic proteases, the caspases, which then orchestrate apoptosis via the cleavage of key substrates. ${ }^{1-4}$ Recent studies have disclosed one key mechanism responsible for initiating the execution phase of apoptosis. Early in the process, release of mitochondrial cytochrome $c,^{5}$ which upon entry into the cytosol forms as complex with Apaf- $1^{6,7}$ and inactive form of caspase- $9 .^{8}$ In the presence of dATP or ATP, this complex activates caspase- 9 , which in turn can trigger a cascade processing and activating the effector caspases-3, -6 , and $-7 .^{8,9}$ This then cleaves key substrates and coordinates the process of apoptotic cell death.

Calphostin C-mediated cell death of human glioma cells has been reported previously to be associated with a marked and rapid down-regulation of $\mathrm{Bcl}-2$ and $\mathrm{Bcl}-\mathrm{x}_{\mathrm{L}}$ proteins and subsequent activation of caspase-3. ${ }^{10,11}$ Calphostin $\mathrm{C}$ is a microbial compound isolated from Cladosporium cladosporioides and a highly potent and specific inhibitor of protein kinase $C$, interacting not with the catalytic domain, but with the regulatory domain. ${ }^{12} \mathrm{Bcl}-2$ family proteins can have profound effects on apoptosis and play a pivotal role in controlling life and death. Proapoptotic Bax plays a crucial role in the apoptotic process via a number of different mechanism, ${ }^{13-16}$ and the genetic approach using knockout mice has recently indicated that Bax can clearly promote apoptosis in the absence of Bcl$2 .{ }^{17}$ The pretreatment with a pan-caspase inhibitor, benzyloxycarbonyl-Val-Ala-Asp-fluoromethylketone (zVAD.fmk), inhibited calphostin C-induced activation of caspase-3 as well as apoptotic nuclear damages (chromatin condensation and DNA fragmentation) and cell shrinkage but did not block calphostin C-induced surface blebbing and cell death, ${ }^{11}$ suggesting the involvement of Bax in calphostin C-induced apoptosis as indicated by Xiang et al. ${ }^{18}$ Bax has been shown to have both cytosolic and membrane-associated location. Death signals such as IL-3 withdrawal, staurosporine, dexamethasone, and $\gamma$ irradiation induce the translocation of Bax protein from cytosol to mitochondrial membrane $e^{15,19,20-22}$ and subsequent all mitochondrial hallmarks of apoptosis. For example, Bax induces directly cytochrome $c$ release from mitochondria and caspase activation in vivo ${ }^{23,24}$ and in vitro. $^{24-26}$ Anti-apoptotic $\mathrm{Bcl}-2$ and $\mathrm{Bcl}-\mathrm{x}_{\mathrm{L}}$ have been shown to be capable of blocking spontaneous cytochrome $c$ release in cell-free extracts and in cells treated with apoptosis-inducing agents. ${ }^{5,24,27-29}$ The cytochrome $c$ release has been also reportedly dependent upon induction of the mitochondrial permeability transition which is associated with disruption of $\Delta \Psi \mathrm{m}^{30,31}$ and has been 
implicated in a variety of apoptotic phenomena. ${ }^{32-35}$ However, this release can occur in the absence of a decrease in $\Delta \Psi \mathrm{m}$ in both cell-free systems and in cells undergoing apoptosis. ${ }^{24,27,28,36}$ Therefore, we examine whether Bax is involved in calphostin C-mediated cell death through the translocation to mitochondria as a result of down-regulation of $\mathrm{Bcl}-2$ and $\mathrm{Bcl}-\mathrm{x}_{\mathrm{L}}$, and evaluate the relationships between the translocation of Bax, release of cytochrome $c$, disruption of $\Delta \Psi \mathrm{m}$, and activation of caspase-3.

\section{Results}

\section{Bax redistributes and homodimerizes in mitochondria}

Bcl-2 was shown as a single $26 \mathrm{kDa}$ peptide by immunoblot analysis and $\mathrm{Bcl}-\mathrm{x}_{\mathrm{L}}$ as a doublet of peptides with an apparent molecular mass of $29-31 \mathrm{kDa}$. Bcl-2 and $\mathrm{Bcl}-\mathrm{x}_{\mathrm{L}}$ were downregulated nearly synchronously as early as $1 \mathrm{~h}$ after treatment with $100 \mathrm{nM}$ calphostin C in both U-87MG and T98G cells (Figure 1) and were barely detected as early as $4 \mathrm{~h}$ in $\mathrm{U}$ 87MG cells and $8 \mathrm{~h}$ in T98G cells after calphostin C treatment. ${ }^{11}$ In addition, $29 \mathrm{kDa} \mathrm{Bcl}-\mathrm{x}_{\mathrm{L}}$ isoform was denser than $31 \mathrm{kDa}$ one before calphostin $\mathrm{C}$ treatment whereas both $\mathrm{Bcl}-\mathrm{x}_{\mathrm{L}}$ isoforms became similar in density with each other as early as $2 \mathrm{~h}$ after $100 \mathrm{nM}$ calphostin $\mathrm{C}$ treatment, indicating a mobility shift of $\mathrm{Bcl}-\mathrm{x}_{\mathrm{L}}$.

The present study of Bax distribution demonstrates that Bax is found substantially in the soluble S100 cytosolic fraction and moderately in the mitochondria-enriched $\mathrm{HM}$ fraction as documented by the mitochondrial marker such as cytochrome $c$ oxidase (Figure 2A). In contrast, Bcl-2 was shown predominantly in mitochondria-rich $\mathrm{HM}$ as well as endoplasmic reticulum- and plasma membrane-rich LM fractions and moderately in $\mathrm{P} 1$ fraction, which is comprised of residual whole cells, nuclei and some mitochondria (Figure 2A). Finally, Bcl- $x_{L}$ was found mainly in $\mathrm{HM}$ fraction and moderately to slightly in other three fractions (Figure $2 \mathrm{~A})$. These results indicate that $\mathrm{Bax}, \mathrm{Bcl}-2$, and $\mathrm{Bcl}-\mathrm{x}_{\mathrm{L}}$ are differentially compartmentalized with Bax being predominantly soluble, $\mathrm{Bcl}-2$ being exclusively membrane-bound, and $\mathrm{Bcl}-\mathrm{x}_{\mathrm{L}}$ being present in both soluble and membranebound forms.

Although immunoreactive levels of Bax were not changed during treatment with $100 \mathrm{nM}$ calphostin $\mathrm{C}$ in both U-87MG and T98G cells, ${ }^{11}$ most of Bax moved from the cytosol mainly to the mitochondrial $\mathrm{HM}$ fraction and partly to $\mathrm{P} 1$ fraction (Figure $2 \mathrm{~A}$ ) following the exposure to $100 \mathrm{nM}$ calphostin $\mathrm{C}$. In contrast, $\mathrm{Bcl}-2$ and $\mathrm{Bcl}-\mathrm{x}_{\mathrm{L}}$ in each compartment were markedly reduced following the exposure to $100 \mathrm{nM}$ calphostin C probably as a result of their down-regulation. Constitutive $\mathrm{Bcl}-2$ in $\mathrm{HM}$ fraction was resistant to extraction at alkaline $\mathrm{pH}$ as a result of its

\section{U-87 MG}

$\begin{array}{llllll}0 & 0.5 & 1 & 2 & 3 & (h)\end{array}$

$\mathrm{BCl}-2$

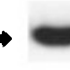

0

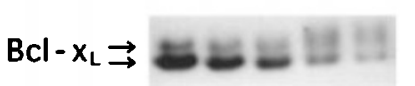

T98G

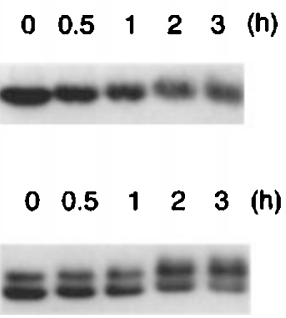

Figure 1 Immunoblot analysis showing $\mathrm{Bcl}-2$ protein as a single band (thick arrows) and $\mathrm{Bcl}-\mathrm{x}_{\mathrm{L}}$ protein as a doublet (thin arrows). Glioma cells (U-87MG and T98G) were exposed to $100 \mathrm{nM}$ calphostin $\mathrm{C}$ for $0.5-3 \mathrm{~h}$, and steady-state level of each protein was monitored by immunoblot analysis. Results are representative of three separate experiments with comparable outcomes

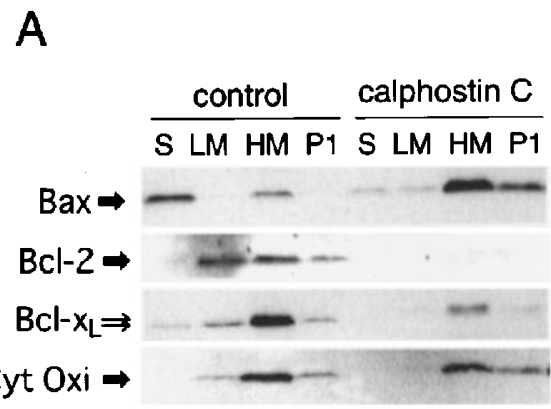

B

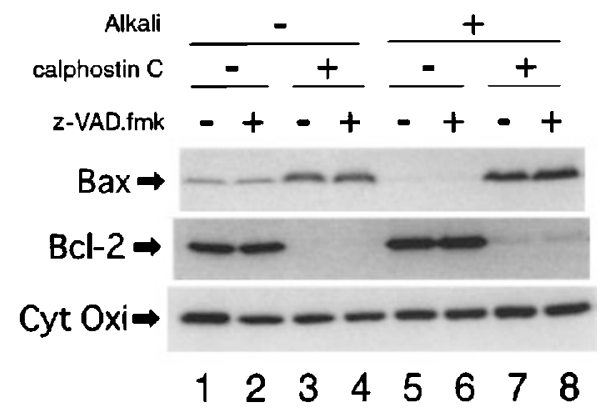

Figure 2 Translocation and integration of Bax into mitochondria. (A) Cytosol-to-membrane distribution of Bax and down-regulation of Bcl-2 and Bcl- $x_{\mathrm{L}}$ in T98G cells following treatment with $100 \mathrm{nM}$ calphostin $\mathrm{C}$ for $6 \mathrm{~h}$ are shown. Control and treated cells were suspended in isotonic buffer, homogenized and separated into soluble S100 fraction (S), light membrane fraction (LM), heavy membrane fraction (HM), and low speed pellet (P1) by differential centrifugation. The P1 pellet contains residual whole cells, nuclei and mitochondria. The HM fraction is enriched for intact mitochondria. The LM fraction contains the endoplasmic reticulum and plasma membrane, and the $\mathrm{S}$ fraction represents the cytosol. The fractions were analyzed by immunoblot with anti-Bax, anti-Bcl-2, anti-Bcl-x, and anti-cytochrome C oxidase subunit II (Cyt Oxi) antibodies. (B) Monomeric Bax in HM fraction of T98G cells was alkali-sensitive before calphostin C treatment and became alkaliresistant after calphostin $\mathrm{C}$ treatment for $6 \mathrm{~h}$, indicative of integration of Bax into mitochondrial membrane after calphostin $\mathrm{C}$ treatment. Bcl-2 in HM fraction of T98G cells was alkali-resistant before and after calphostin $\mathrm{C}$ treatment for $6 \mathrm{~h}$. In addition, the resistance of Bax and Bcl-2 in HM fraction to alkali extraction was not reduced by $100 \mu \mathrm{M}$ z-VAD.fmk. Bax and Bcl-2 in HM fraction prepared from cells treated without or with calphostin C in the absence or presence of z-VAD.fmk were analyzed either directly (lanes 1-4) or after extraction with $0.1 \mathrm{M} \mathrm{Na}_{2} \mathrm{CO}_{3}, \mathrm{pH} 11.5$ (lanes 5-8), as described in $\mathbf{A}$. Similar results were achieved in three separate experiments in $\mathbf{A}$ and $\mathbf{B}$, respectively 
integration into the membrane lipid bilayer as suggested by Nguyen et $a l^{37,38}$ but the majority of constitutive monomeric Bax was liberated from $\mathrm{HM}$ fraction under the same conditions before the exposure to calphostin C (Figure 2B), indicative of a peripheral association of monomeric Bax with the organelle as suggested by Fujiki et al. ${ }^{39}$ After the exposure to $100 \mathrm{nM}$ calphostin $\mathrm{C}$ for $6 \mathrm{~h}$, however, this situation was reversed and most of the monomeric Bax in $\mathrm{HM}$ fraction now acquired resistance to alkaline extraction (Figure 2B), indicative of an integral membrane position as suggested by Goping et al. ${ }^{20}$ Furthermore, the translocation and integration of monomeric Bax into mitochondrial membrane in response to calphostin $C$ was not blocked by $100 \mu \mathrm{M}$ z-VAD.fmk and $10 \mu \mathrm{M}$ oligomycin, a pharmacological inhibitor of proton pump, as shown in Figures $2 \mathrm{~B}$ and $3 \mathrm{~A}$, respectively. We conclude, therefore, that monomeric Bax demonstrates a specific response to the exposure to calphostin $C$ in vivo, moving from the cytosol to the mitochondria and from a membrane-peripheral to a membrane-integrated position in the mitochondria. The increase of monomeric Bax levels in mitochondria, namely the translocation of monomeric Bax, was detected as early as $1 \mathrm{~h}$ after treatment with $100 \mathrm{nM}$ calphostin $\mathrm{C}$ and then gradually enhanced in both U-87MG and T98G cells (Figure 3B).

In the absence of nonionic detergent Bax fails to form homodimers or heterodimers with $\mathrm{Bcl}-\mathrm{x}_{\mathrm{L}}$ and nonionic detergent is capable to enable the homodimerization of Bax. $^{40}$ Consequently, we utilized membrane-impermeable $\mathrm{BS}^{3}$ non-cleavable primary amine cross-linker to assess the conformation of mitochondrial-associated Bax. Before the exposure to calphostin C, Bax could be barely cross-linked as a $42 \mathrm{kDa}$ presumptive homodimer with $\mathrm{BS}^{3}$ (Figure $3 \mathrm{~A}, \mathrm{~B})$. However, $\mathrm{BS}^{3}$-cross-linkable Bax homodimers were formed as early as 4-6 $\mathrm{h}$ (Figure $3 \mathrm{~A}, \mathrm{~B}$ ) and markedly increased as early as $8 \mathrm{~h}$ (Figure 3B) after the exposure to $100 \mathrm{nM}$ calphostin $\mathrm{C}$ in both U-87MG and T98G cells. The levels of translocated monomeric Bax were not decreased after Bax homodimers were formed but rather increased at similar pace to that before Box homodimerization (Figure $3 \mathrm{~B})$, suggesting that the translocated monomeric Bax is partly homodimerized. The homodimerization of Bax was not affected by $100 \mu \mathrm{M} z$-VAD.fmk but moderately inhibited by $10 \mu \mathrm{M}$ oligomycin. Bcl-2 in mitochondria was decreased, on the other hand, as early as $1 \mathrm{~h}$ and barely detectable as early as $8 \mathrm{~h}$ after exposure to $100 \mathrm{nM}$ calphostin $\mathrm{C}$ in both U-87 MG and T98G cells (Figure 3B), suggesting its downregulation.

\section{Cytochrome $c$ release and caspase-3 activation}

$\mathrm{Bcl}-2$ and $\mathrm{Bcl}-\mathrm{x}_{\mathrm{L}}$ are reported to inhibit cytochrome $c$ release from mitochondria, ${ }^{5,27,28}$ whereas Bax induces cytochrome $c$ release. ${ }^{23-26}$ Therefore, we examined by immunoblot analysis whether cytochrome $c$ is released from mitochondria into cytosol in calphostin C-induced apoptosis. Immunoreactive cytochrome $c$ in $\mathrm{S} 100$ cytosolic fractions increased slightly as early as $2 \mathrm{~h}$ in U-87MG cells and $1-2 \mathrm{~h}$ in T98G cells after treatment with $100 \mathrm{nM}$ calphostin C, namely concurrent with or just after the translocation of Bax to
A

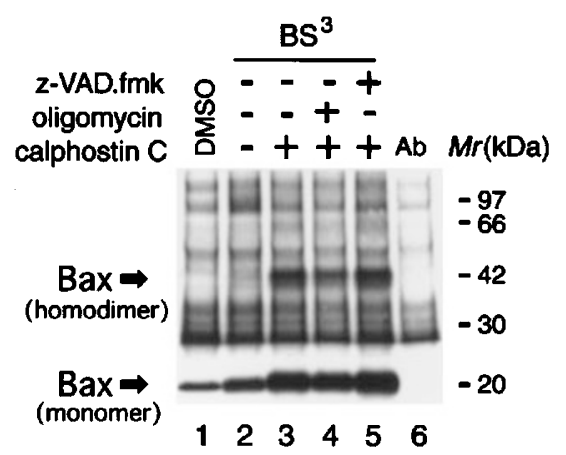

B
U-87 MG

012468 (h)

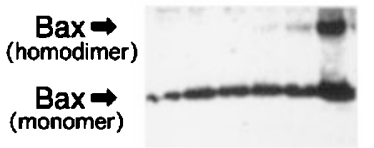

012468 (h)

$\mathrm{Bcl}-2=$
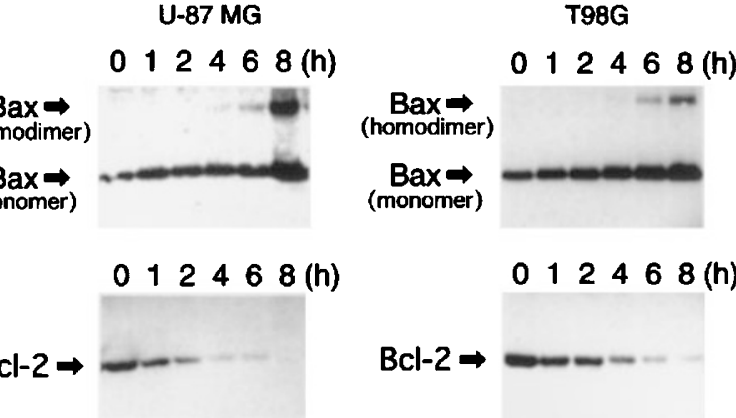

Figure 3 A marked increase in Bax homodimers and monomers following treatment with $100 \mathrm{nM}$ calphostin C (A) Heavy membranes prepared from T98G cells treated without (lanes 1-2) or with calphostin $C$ for $6 \mathrm{~h}$ (lanes $3-5$ ) in the absence or presence of $100 \mu \mathrm{M} z-V A D$.fmk or $10 \mu \mathrm{M}$ oligomycin were incubated with $10 \mathrm{mM}$ membrane-impermeable $\mathrm{BS}^{3}$ (lanes 2-5) cross-linker, or with DMSO as a control (lane 1). After incubation, membranes were quenched and lysed, Bax was immunoprecipitated with anti-Bax monoclonal antibody (4F11), size-fractionated by polyacrylamide gel electrophoresis and analyzed by immunoblot with anti-Bax polyclonal antibody. The $4 \mathrm{~F} 11$ monoclonal antibody was run as a control (lane 6). (B) Heavy membranes prepared from U-87MG and T98G cells exposed to calphostin $\mathrm{C}$ for $1-8 \mathrm{~h}$ were treated with $10 \mathrm{mM}$ membrane-impermeable $\mathrm{BS}^{3}$ cross-linker. After treatment, membranes were lysed and analyzed by immunoblot with anti-Bax polyclonal antibody. The membranes were reprobed with anti-Bcl-2 antibody (6C8), showing down-regulation of $\mathrm{Bcl}-2$. Results are representative of three independent experiments with comparable outcome

mitochondria, and then enhanced maximally at 6-8 $\mathrm{h}$ in $\mathrm{U}$ 87MG cells and at $4 \mathrm{~h}$ in T98G cells (Figure 4A), when Bax homodimers were formed and ATP levels were reduced to within about $75 \%$ of control levels (data not shown). In addition, cytochrome $c$ release into the cytosol was not inhibited by $100 \mu \mathrm{M} z-V A D$.fmk or $10 \mu \mathrm{M}$ oligomycin in both U-87MG and T98G cells (Figure 4B).

Previous reports demonstrated that the exposure to $100 \mathrm{nM}$ calphostin $\mathrm{C}$ induced activation of caspase-3 but not caspase-1 in both U-87MG and T98G cells. ${ }^{11}$ Immunoreactive $32 \mathrm{kDa}$ procaspase-3 was degraded into active $12 \mathrm{kDa}$ caspase-3 fragment as early as $6 \mathrm{~h}$ in $\mathrm{U}$ 87MG cells and $4 \mathrm{~h}$ in T98G cells after treatment with $100 \mathrm{nM}$ calphostin $\mathrm{C}$, when cytochrome $c$ was released maximally from mitochondria. The generation of a $\mathrm{COOH}$ terminal $85 \mathrm{kDa}$ PARP apoptosis fragment was shown to 
be associated with the production of active $12 \mathrm{kDa}$ caspase-3 fragment (Figure 5). These data are consistent with caspase-3 activation in calphostin C-treated gliomas. However, the membrane-associated caspase-3 is reported to be not activated in the presence of exogenous cytochrome $c$ and suppresses by expression of $\mathrm{Bcl}-2$, while the cytoplasmic caspase- 3 is robustly activated by cytochrome $c{ }^{41}$ Therefore, the inhibition of the membraneassociated caspase- 3 by $\mathrm{Bcl}-2$ could be reduced by the down-regulation of $\mathrm{Bcl}-2$ induced by calphostin $\mathrm{C}$. However, the activation of caspase- 3 was not detected before the cytochrome $c$ release in calphostin $\mathrm{C}$-induced apoptosis, probably because the amount of membrane-associated caspase activity is small compared with that in the cytoplasmic caspase. ${ }^{41}$

A

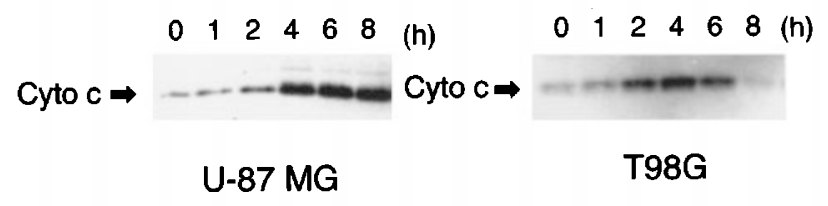

B

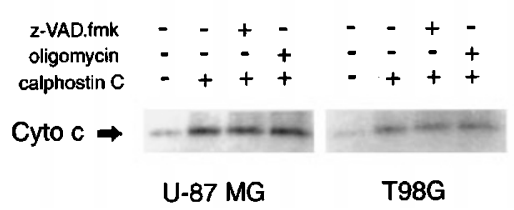

Figure 4 Immunoblot analysis of cytochrome $c$ in $\mathrm{S} 100$ cytosolic fractions of U-87MG and T98G cells treated with $100 \mathrm{nM}$ calphostin $\mathrm{C}$ alone for the indicated times (A) and for $4 \mathrm{~h}$ in the absence or presence of $100 \mu \mathrm{M} \mathrm{z}$ VAD.fmk or $10 \mu \mathrm{M}$ oligomycin (B). Cytochrome $c$ (Cyto $c$ ) in S100 cytosolic fractions was immunologically probed with anti-cytochrome $c$ monoclonal antibody $(7 \mathrm{H} 8.2 \mathrm{C} 12)$. The results are from a representative study performed three times with comparable outcomes

\section{U-87 MG}

T98G

\section{caspase-3}
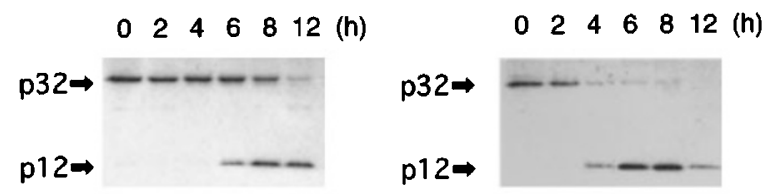

\section{PARP}
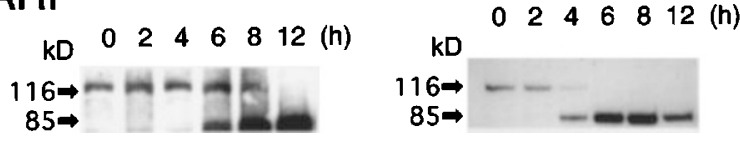

Figure 5 Immunoblot analysis showing activation of caspase-3 associated with cleavage of PARP. Formation of active $12 \mathrm{kDa}$ caspase- 3 fragment from $32 \mathrm{kDa}$ procaspase- 3 in both $\mathrm{U}-87 \mathrm{MG}$ and T98G cells, indicating activation of caspase-3. Cleavage of $116 \mathrm{kDa}$ PARP into an $85 \mathrm{kDa}$ apoptotic fragment was monitored by immunoblot analysis. Similar results were achieved in three separate experiments

\section{Dissipation of mitochondrial $\Delta \Psi \mathrm{m}$}

In many systems, apoptosis is associated with a loss of mitochondrial $\Delta \Psi \mathrm{m}$. Therefore, we examined $\Delta \Psi \mathrm{m}$ in calphostin $\mathrm{C}$-induced apoptosis using $\mathrm{DiOC}_{6}(3)$, a fluorochrome. $\mathrm{DiOC}_{6}(3)$-based measurement of $\Delta \Psi \mathrm{m}$ demonstrated a marked dissipation as early as $3 \mathrm{~h}$ in U-87MG cells and $2 \mathrm{~h}$ in T98G cells after treatment with $100 \mathrm{nM}$ calphostin $\mathrm{C}$, namely after the translocation of Bax and the release of cytochrome $c$ (Figure $6 \mathrm{~A}$ ). Acute exposure of cells to the protonophore $\mathrm{mCICCP}$ confirmed that the $\mathrm{DiOC}_{6}(3)$ staining was dependent on the inner mitochondrial membrane potential, thus verifying the specificity of this assay. In addition, the decrease in $\Delta \Psi \mathrm{m}$ induced by $100 \mathrm{nM}$ calphostin C was unaffected by $100 \mu \mathrm{M}$ z-VAD.fmk (Figure 6B,C), showing no decrease in the number of cells displaying the low $\Delta \Psi \mathrm{m}$.

\section{Oligomycin inhibits calphostin C-induced apoptosis and activation of caspases}

Oligomycin binds to the $F_{0}$ portion of the mammalian $\mathrm{F}_{0} \mathrm{~F}_{1}$-ATPases and prevents the proton pump from transporting $\mathrm{H}^{+}$ions, thus effectively shutting it off. ${ }^{42}$ Since oligomycin is toxic in mammalian cells, the experiments were performed before oligomycin caused cell death ( $>90 \%$ trypan blue dye exclusion in control cultures). As shown in Figure 7A, oligomycin reduced the percentage of apoptotic cells in dose-dependent manner, with $10 \mu \mathrm{M}$ oligomycin preventing approximately more than half of the calphostin $\mathrm{C}$-induced cell death. $\mathrm{DiOC}_{6}(3)$-based measurement of $\Delta \Psi \mathrm{m}$ demonstrated that $10 \mu \mathrm{M}$ oligomycin resulted in hyperpolarization of mitochondria in glioma cells (Figure 7B), consistent with a block of the proton pump causing accumulation of $\mathrm{H}^{+}$ ions in the intermembrane space of mitochondria. In contrast to oligomycin, the respiratory complex III inhibitor antimycin A did not impair calphostin C-induced apoptosis (Figure 7A), but did reduce mitochondrial $\Delta \Psi \mathrm{m}$ (Figure 7B).

Since gene transfer-mediated overexpression of Bax has been shown to induce activation of caspases that can cleave the substrate peptide DEVD, ${ }^{25,43}$ we measured the effects of oligomycin treatment on calphostin C-induced activation of DEVD-cleaving caspases using lysates from glioma cells. As shown in Figure 7C, calphostin C-treated glioma cells contained markedly elevated levels of caspase activity compared to control cells. Addition of $10 \mu \mathrm{M}$ oligomycin to the cultures had no effect on cytochrome $c$ release (Figure 4 ) but substantially reduced the amount of calphostin C-induced caspase activity (Figure 7C). Following the treatment with $100 \mathrm{nM}$ calphostin $\mathrm{C}$ for $6 \mathrm{~h}$, glioma cells showed apoptotic morphological features (Figure 7D): cell shrinkage and surface blebbing by phase contrast images as well as nuclear condensation and fragmentation by Hoechst 33258 stain. However, the addition of $10 \mu \mathrm{M}$ oligomycin induced marked decrease in cell shrinkage as well as chromatin condensation and fragmentation, suggesting the inactivation of caspase-3. 
A

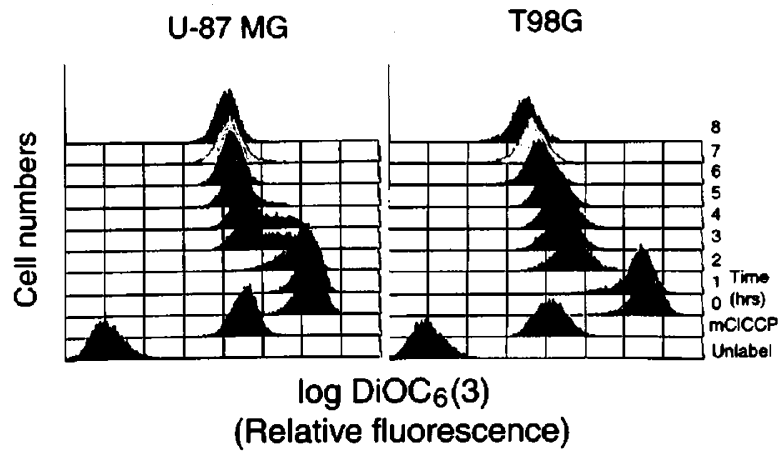

B

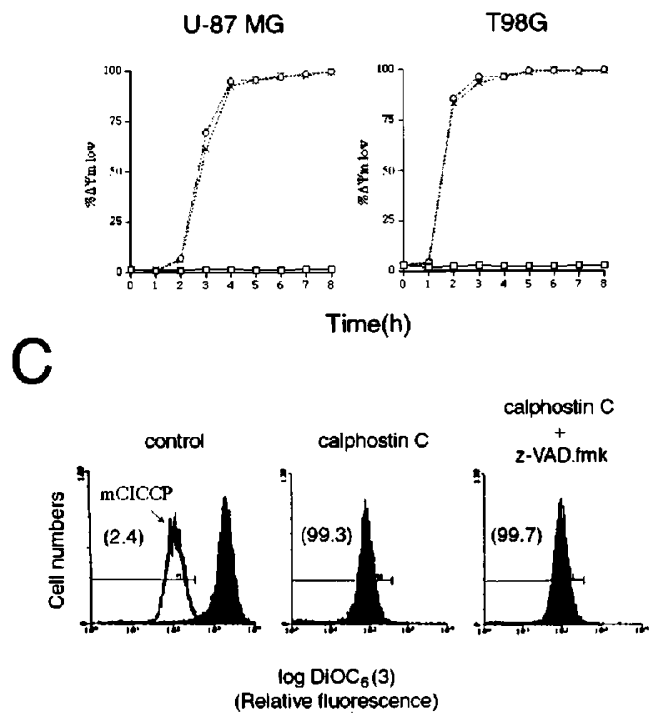

Figure 6 Calphostin $\mathrm{C}$ inducing reduction of the mitochondrial $\triangle \Psi \mathrm{m}$. (A) U-87MG and T98G cells were treated with $100 \mathrm{nM}$ calphostin $\mathrm{C}$ for the indicated times and incubated with $\operatorname{DiOC}_{6}(3)$, followed by FACS analysis. Data represent log fluorescence versus relative cell number. As a control for specificity of DiOC $6(3)$ labeling, an aliquot of the control untreated cells was exposed to the protonophore mCICCP for 15 min prior to incubation with DiOC 6 (3). (B) Time course analysis of mitochondrial permeability transition after U-87MG and T98G cells were treated with or without $100 \mu \mathrm{M} z-V A D$.fmk and then with $100 \mathrm{nM}$ calphostin C. Samples were analyzed at the indicated time points for mitochondrial depolarization as described in $\mathbf{A}$. open squares, no treatment; open circles, treatment with calphostin C; crosses, treatment with z-VAD.fmk plus calphostin C. (C) Histograms show $\mathrm{DiOC}_{6}(3)$ staining of T98G cells induced by $100 \mathrm{nM}$ calphostin $\mathrm{C}$ for $6 \mathrm{~h}$ in the presence or absence of $100 \mu \mathrm{M} \mathrm{z}$-VAD.fmk. mCICCP that completely disrupt the $\Delta \Psi \mathrm{m}$, was used as a positive control. The numbers in parenthesis represent the percentage of $\Delta \Psi \mathrm{m}^{\text {low }}$ cells. Similar results were obtained in three separate experiments in $\mathbf{A}, \mathbf{B}$, and $\mathbf{C}$, respectively

\section{Discussion}

In the present study, we have shown that calphostin $C$ induces down-regulation of anti-apoptotic Bcl-2 and $\mathrm{BCl}-\mathrm{x}_{\mathrm{L}}$ as well as concurrent translocation of pro-apoptotic monomeric Bax to mitochondria, followed by release of cytochrome $c$, dissipation of $\Delta \Psi \mathrm{m}$, and activation of caspase-3. The previous study demonstrated that caspase inhibitors did not block calphostin C-induced cell death. ${ }^{11}$ In addition, the genetic approach using knockout mice indicated that Bax promoted apoptosis in the absence of Bcl-2. ${ }^{17}$ These observations, taken together, suggest the involvement of Bax in calphostin C-mediated apoptosis. In addition, $10 \mu \mathrm{M}$ oligomycin inhibits calphostin C-induced apoptosis and activation of caspase-3, probably because intact $F_{0} F_{1}$-ATPase in the inner mitochondrial membrane is necessary for optimal function of Bax as shown by Matsuyama et al. $^{44} \mathrm{Bax}$, although present in many cell types, does not trigger apoptosis on its own but rather promotes apoptosis induced by removal of growth factors and other stimuli, ${ }^{13,15,45,46}$ and in some cases, ectopic expression of Bax can induce apoptosis. ${ }^{18,24,31,47,48}$ Therefore, despite no evidence of any alterations of Bax levels in calphostin C-induced apoptosis, ${ }^{11}$ the translocation of proapoptotic monomeric Bax concurrent with the downregulation of anti-apoptotic $\mathrm{Bcl}-2$ and $\mathrm{Bcl}-\mathrm{x}_{\mathrm{L}}$ seems to leave glioma cells prone to apoptosis. The signals and mechanisms responsible for the change in Bax distribution are not known. Bcl-2 blocked the translocation of monomeric Bax in response to a death signal. ${ }^{15,21,49}$

The present study demonstrates that the translocation of Bax is associated with the acquirement of resistance to alkali extraction. Bax in $\mathrm{HM}$ fraction before calphostin $\mathrm{C}$ treatment did not exhibit any resistance to alkali extraction. A recent report has indicated that, during apoptosis, the association of Bax with mitochondrial membranes changes from a weak to a strong insertion as suggested by an acquirement of resistance to alkali extraction, a process which is regulated by the $\mathrm{NH}_{2}$-terminal domain of Bax. ${ }^{20}$ Altogether, these results suggest that Bax undergoes a conformational change after translocation to mitochondria induced by calphostin $\mathrm{C}$. The Bax-conformational changes in calphostin $\mathrm{C}$-induced apoptosis were not blocked by $100 \mu \mathrm{M}$ z-VAD.fmk or $10 \mu \mathrm{M}$ oligomycin. No inhibition of Bax-conformation by the latter suggests that Bax-conformation is not prevented by loss of the proton pump in the inner mitochondrial membrane. As a working hypothesis, we propose that Bax remains weakly attached to mitochondria in the absence of apoptotic stimulus, and that Bax which is translocated to mitochondria by exposure to calphostin $\mathrm{C}$ modifies the structure of Bax leading to its insertion into mitochondrial membranes.

How does calphostin $C$ induce the release of cytochrome $c$ ? The cytochrome $c$ release was shown before the activation of caspase-3 and not inhibited by $100 \mu \mathrm{M} z-$ VAD.fmk in calphostin C-mediated apoptosis, suggesting 
A

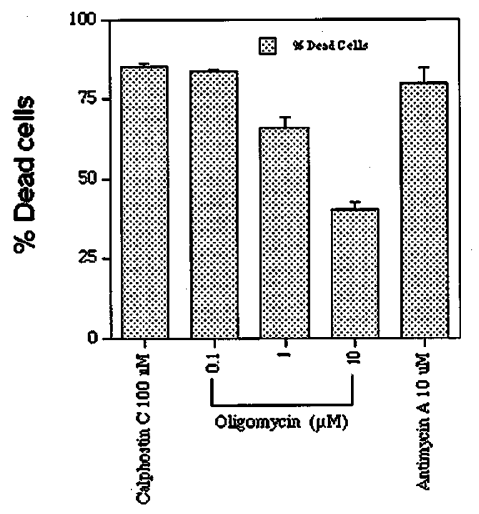

C

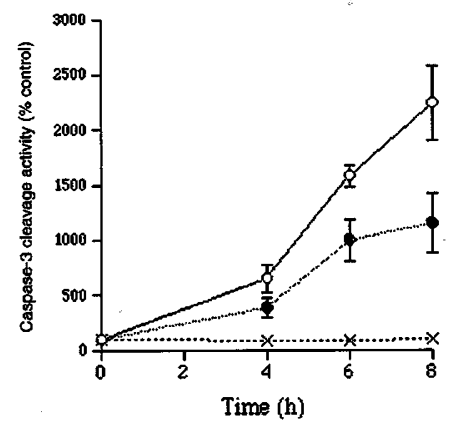

B

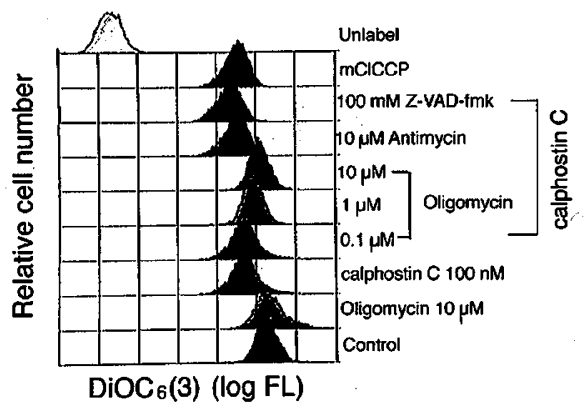

control oligomycin calphostin C

\section{calphostin C $+$ oligomycin}

\section{Phase Contrast}

Hoechst
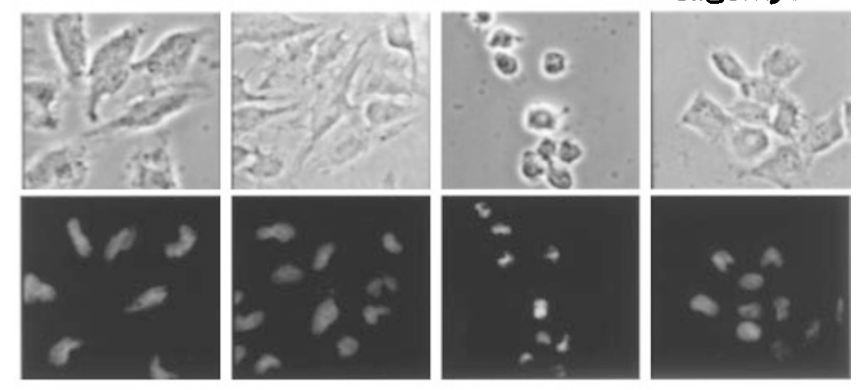

Figure 7 Oligomycin suppresses calphostin C-induced apoptosis and caspase activation in T98G cells. (A) Cells were treated with $100 \mathrm{nM}$ calphostin $\mathrm{C}$ for $8 \mathrm{~h}$ in the absence or presence of $0.1,1$, or $10 \mu \mathrm{M}$ oligomycin or $10 \mu \mathrm{M}$ antimycin $\mathrm{A}$. The percentage of nonviable cells was determined by trypan blue dye exclusion method. (B) Cells were treated with $10 \mu \mathrm{M}$ oligomycin alone for $4 \mathrm{~h}$ or with $100 \mathrm{nM}$ calphostin $\mathrm{C}$ for $4 \mathrm{~h}$ in the absence or presence of 0.1 , 1 , or $10 \mu \mathrm{M}$ oligomycin, $10 \mu \mathrm{M}$ antimycin $\mathrm{A}$, or $100 \mu \mathrm{M}$ z-VAD.fmk, and were incubated with $\mathrm{DiOC}_{6}(3)$, followed by FACS analysis. Data represent log fluorescence versus relative cell number. As a control for specificity of $\mathrm{DiOC}_{6}(3)$ labeling, an aliquot of the control untreated cells was exposed to the protonophore $\mathrm{mCICCP}$ for 15 min prior to incubation with $\mathrm{DiOC}_{6}(3)$. (C) Lysate derived from cells treated with $100 \mathrm{nM}$ calphostin $\mathrm{C}$ for the indicated times in the absence or presence of $10 \mu \mathrm{M}$ oligomycin were prepared and normalized for total protein content, and caspase-3 activity was measured based on hydrolysis of DEVD-MCA: open circles, treatment with calphostin C; crosses, treatment with oligomycin; closed circles, treatment with calphostin C plus oligomycin. (D) Representative photographs of phase contrast images and Hoechst 33258 stain of T98G treated with $100 \mathrm{nM}$ calphostin C for $6 \mathrm{~h}$ in the absence or presence of $10 \mu \mathrm{M}$ oligomycin. Phase contrast $\times 200$; Hoechst 33258 stain $\times 200$. The results of $\mathbf{A}, \mathbf{B}, \mathbf{C}$ and $\mathbf{D}$ are from representative study performed in three experiments with comparable outcomes

that it occurs independently of caspase-3 activation, as reported by Bossy-Wetzel et $a^{36}$ in staurosporine-and UVB irradiation-induced apoptosis and by Finucane et $\mathrm{al}^{24}$ in Bax-transfected apoptosis. In addition, the down-regulation of $\mathrm{Bcl}-2$ and $\mathrm{Bcl}-\mathrm{x}_{\mathrm{L}}$ in calphostin $\mathrm{C}$-induced apoptosis suggests an incapability of preventing cytochrome $c$ release. Therefore, the cytochrome $c$ release from the intermembrane space of mitochondria in calphostin Cinduced apoptosis is a direct effect of Bax on the outer mitochondrial membrane as reported in other apoptosis by Rossé et al, ${ }^{23}$ Jürgensmeier et al ${ }^{25}$ and Finucane et al. ${ }^{24}$ Although Bax-induced cytochrome $c$ release was reported to be inhibited by $10 \mu \mathrm{M}$ oligomycin in isolated mitochondria, ${ }^{50}$ calphostin $C$-induced cytochrome $c$ release was not blocked by oligomycin when cytochrome $c$ in cytosolic S100 fraction was examined. Thus, the treatment with oligomycin did not induce any alterations in monomeric Bax levels in mitochondria and cytochrome $c$ release from mitochondria. Since cytochrome $c$ release was induced following the translocation of monomeric Bax in calphostin C-mediated apoptosis, the nature of the translocation signal of monomeric Bax leading to induction of cytochrome $c$ release potentially takes on significance as a major apoptotic signaling pathway. It has been suggested also that the loss of $\Delta \Psi \mathrm{m}$ is responsible for the cytochrome $c$ release, ${ }^{30}$ but the cytochrome $c$ release was shown before the decrease in $\Delta \Psi \mathrm{m}$ in calphostin $\mathrm{C}$-induced apoptosis as reported by Yang et $a l^{27}$ and Kluck et $a l^{28}$ in other apoptosis, suggesting that the loss of $\Delta \Psi \mathrm{m}$ is not required for the cytochrome $c$ release. Recently, Vander Heiden et $a l^{51}$ provided evidence that during apoptosis, a hyperpolarization of the mitochondrial inner membrane causes a swelling that might act to puncture the outer membrane without necessarily disrupting $\Delta \Psi \mathrm{m}$ in the short term, but it 
remains to be determined whether mitochondrial swelling occurs in calphostin C-mediated apoptosis.

The decrease in $\Delta \Psi \mathrm{m}$ induced by $100 \mathrm{nM}$ calphostin $\mathrm{C}$ was detectable following the translocation of Bax to mitochondria. Finucane et $\mathrm{al}^{24}$ have reported that any decrease in $\Delta \Psi \mathrm{m}$ is not detected in isolated mitochondria treated with Bax despite the release of cytochrome $c$, but Bax protein has been shown to induce alterations in $\Delta \Psi \mathrm{m}$ in vivo. ${ }^{18,24,31,52}$ Bax protein binds to PTPC, a composite proteaceous channel that is involved in the regulation of mitochondrial membrane permeability, and Bax and adenine nucleotide translocator, a constitutive mitochondrial protein, cooperate within the PTPC to increase mitochondrial membrane permeability. ${ }^{52}$ The decrease in $\Delta \Psi \mathrm{m}$ induced by $100 \mathrm{nM}$ calphostin $\mathrm{C}$ was ameliorated by $10 \mu \mathrm{M}$ oligomycin. Since cellular ATP levels were higher in cells treated with calphostin $C$ and oligomycin than those treated with calphostin C alone (data not shown), it is conceivable that Bax integrated into mitochondria in calphostin C-mediated apoptosis renders the outer membrane more porous, causing a faster dissipation of the proton gradient than usual through leakage of $\mathrm{H}^{+}$ions into the cytosol. Consequently, the $F_{0} F_{1}$-ATPase proton pump would run in reverse direction, thus consuming ATP and alkalinizing the matrix by extruding protons to cause opening of the mitochondrial PTPC. ${ }^{53,54}$ The decrease in $\Delta \Psi \mathrm{m}$ in calphostin $\mathrm{C}$-induced apoptosis was unaffected by $100 \mu \mathrm{M}$ z-VAD.fmk, consistent with the observations of Xiang et $a l^{18}$ in Bax-induced cell death and by Marzo et $a l^{52}$ in Bax microinjection, but Finucane et $a^{24}$ have found that the addition of $100 \mu \mathrm{M}$ z-VAD.fmk substantially decreases the number of cells displaying the loss of $\Delta \Psi \mathrm{m}$, suggesting requirement of cytosolic participation for the decrease of $\Delta \Psi \mathrm{m}$. Calphostin $\mathrm{C}$ triggers a rapid caspase-dependent apoptosis, but even if caspase activity is inhibited, a nonapoptotic cell death proceeds. ${ }^{11}$ In calphostin $\mathrm{C}$-induced cell death, the release of cytochrome $c$ might be expected to result in disruption of electron transport, inducing the decrease in ATP which is not so prominent in the early stage (data not shown) but may ultimately cause cell death even in the absence of caspase function. The translocation of monomeric Bax from the cytosol to mitochondria is accompanied by the integration of monomeric Bax into mitochondria and is followed by cytochrome $c$ release and the dissipation of $\Delta \Psi \mathrm{m}$ before the homodimerization of $\mathrm{Bax}$ in calphostin $\mathrm{C}$-induced apoptosis. Bcl-2 inhibits the homodimerization of Bax in response to death signal, ${ }^{15,21,49}$ and enforced dimerization of FKBP-Bax by the bivalent ligand FK1012 overrode the anti-apoptotic protection of $\mathrm{Bcl}-\mathrm{x}_{\mathrm{L}}{ }^{21}$ Since $\mathrm{Bcl}-2$ and $\mathrm{Bcl}-\mathrm{x}_{\mathrm{L}}$ were down-regulated in calphostin $\mathrm{C}$-induced cell death, Bax could be homodimerized without any inhibition. Although the homodimerization of Bax and the pore formation of Bax are shown to be required for the proapoptotic effect of $\mathrm{Bax},{ }^{21,52}$ the present study suggests that translocated monomeric Bax is associated with Baxconformational change and capable of inducing mitochondrial hallmarks of apoptosis, and that the Bax homodimerization is rather associated with the later maximum release of cytochrome $c$ and the marked decrease in ATP levels (less than $30 \%$ of control; data not shown). Although the $\mathrm{BH} 3$ domain of the pro-apoptotic family members is crucial for their death-promoting and protein binding functions, BH3-independent mechanism of cell killing has been obtained through experiments involving $\mathrm{BH} 3$ domain mutants of Bax. ${ }^{55,56}$ In addition, Bax mutant mlll-1 which replaces hydrophobic face of $\mathrm{BH} 3$ with alanines, fails to form homodimers or heterodimers in classic binding assays but still inserts into mitochondrial membranes as a crosslinkable pair to induce apoptosis. ${ }^{57}$ The homodimerization of Bax in mitochondria was decreased in the presence of $10 \mu \mathrm{M}$ oligomycin, suggesting that the $\mathrm{F}_{0} \mathrm{~F}_{1}$-ATPase activity in the inner mitochondrial membrane is involved in the homodimerization of Bax.

The important question which remains to be understood is why the cells, despite showing significant levels of mitochondria-associated Bax, do not spontaneously undergo apoptosis. Dose Bax remain inactive because of possible association with anti-apoptotic proteins such as $\mathrm{Bcl}-2$ or $\mathrm{Bcl}-\mathrm{x}_{\mathrm{L}}{ }^{13}$ which would interfere with the availability and translocation of Bax from the cytoplasm to the mitochondria, or because of an inert configuration? The data presented here provide that the alkali-resistant integration of Bax into mitochondria is possible explanation to this question. In addition, despite the vast literature dealing with Bax, little is known about how integrated membrane Bax kill the cells. Some clues were provided by the observations that $\mathrm{Bax}, \mathrm{Bcl}-2$ and $\mathrm{Bcl}-\mathrm{x}_{\mathrm{L}}$ form distinct ion-conductive pores. ${ }^{58-61} \mathrm{Bax}$ is reported to have redundant mechanisms for inducing apoptosis, based on its ability to form $\alpha 5$ and $\alpha 6$ helices-dependent channels in membranes and to dimerize with and antagonize antiapoptotic proteins such as $\mathrm{Bcl}-2,{ }^{62}$ and may regulate an electrochemical gradient, alter mitochondrial volume homeostasis, or redistribute critical substrates or products residing in the intermembrane space of mitochondria. Bcl2 and $\mathrm{BCl}-\mathrm{x}_{\mathrm{L}}$ inhibit the redistribution and homodimerization of $\mathrm{Bax}$ in response to a number of apoptosis-inducing stimuli, probably by formation of heterodimers between $\mathrm{Bcl}$ $2 / \mathrm{Bcl}-\mathrm{x}_{\mathrm{L}}$ and $\mathrm{Bax}$ or by counteracting ion channels at the level of the mitochondria. ${ }^{52,63,64}$

\section{Materials and Methods}

\section{Glioma cell culture}

Two human glioma cell lines, wild-type p53-positive U-87 MG and mutant p53-positive T98G cells, were obtained from American Type Culture Collection (Rockville, MD, USA) and were maintained in Dulbecco's modified Eagle's minimum essential medium supplemented with $10 \%$ fetal calf serum and antibiotics $(100 \mathrm{U} / \mathrm{ml}$ penicillin and $100 \mu \mathrm{g} / \mathrm{ml}$ streptomycin) in a humidified atmosphere of $5 \%$ CO2 and $95 \%$ air at $37^{\circ} \mathrm{C}$. Test exposures to $100 \mathrm{nM}$ calphostin $\mathrm{C}$ were conducted in the continuous presence of light to promote photoactivation of this compound.

\section{Immunoblot analysis}

Cells were lysed in TNES buffer $(50 \mathrm{mM}$ Tris- $\mathrm{HCl}$ at $\mathrm{pH} 7.5,100 \mathrm{mM}$ $\mathrm{NaCl}, 1 \% \mathrm{NP}-40,2 \mathrm{mM}$ EDTA, $20 \mu \mathrm{g} / \mathrm{ml}$ leupeptin, $20 \mu \mathrm{g} / \mathrm{ml}$ aprotinin, 
$1 \mathrm{mM}$ PMSF) and centrifuged at $15000 \times \mathrm{g}$ for $10 \mathrm{~min}$. Equivalent amounts of cell lysates were heated in $2 \times$ loading buffer at $95^{\circ} \mathrm{C}$ for $5 \mathrm{~min}$, and then electrophoresed in 12\% SDS-polyacrylamide gel, except for immunoblot of PARP in which $8 \%$ SDS-polyacrylamide ge was used, and transferred onto polyvinylidene difluoride membranes. The membranes were blocked with $5 \%$ skim milk in Tris-buffered saline containing $0.05 \%$ Tween 20 for $3 \mathrm{~h}$, and were incubated with primary antibody against Bcl-2 (6C8: Pharmingen, San Diego, CA, USA), Bcl-x (Transduction Laboratories, Lexington, KY, USA), p12 subunit of caspase-3 (Santa Cruz, Santa Cruz, CA, USA), and PARP (a kind gift from Dr. Guy G Poirier, CHUL Research Cener, Quebec, Canada), washed, and blotted with species-specific biotinylated secondary antibodies (Vector, Burlingame, CA, USA) for $1 \mathrm{~h}$ and then with horseradish peroxidase-streptavidin (Vector) for $1 \mathrm{~h}$. The membrane was then developed in ECL reagent (Amersham, Arlington Heights. IL, USA).

\section{Preparation of subcellular fractions}

Cells were washed once in PBS, resuspended in isotonic buffer $A$ (10 mM HEPES at $\mathrm{pH} 7.5,200 \mathrm{mM}$ mannitol, $70 \mathrm{mM}$ sucrose, $1 \mathrm{mM}$ EGTA) supplemented with protease inhibitors (1 mM PMSF, $10 \mu \mathrm{g} / \mathrm{ml}$ leupeptin, $10 \mu \mathrm{g} / \mathrm{ml}$ pepstatin A, $10 \mu \mathrm{g} / \mathrm{ml}$ soybean trypsin inhibitor and $10 \mu \mathrm{g} / \mathrm{ml}$ aprotinin), and homogenized with 25 strokes of a Teflon homogenizer. Nuclei and unbroken cells were separated at $120 \times g$ for $5 \mathrm{~min}$ as $\mathrm{P} 1$ pellet. This supernatant was centrifuged at $10000 \times g$ for $10 \mathrm{~min}$ to collect HM pellet. This supernatant was centrifuged at $10000 \times g$ for $30 \mathrm{~min}$ to yield LM pellet and final $S 100$ fraction. Hypotonic lysis was performed by resuspending the cells in hypotonic buffer $(10 \mathrm{mM}$ Tris at $\mathrm{pH} 7.5$, $5 \mathrm{mM} \mathrm{MgCl}$, $1 \mathrm{mM}$ EGTA, $1 \mathrm{mM} \mathrm{DTT)}$ and homogenized with a Dounce homogenizer. For alkali extraction, the HM fraction was resuspended $(0.25 \mathrm{mg}$ protein $/ \mathrm{ml})$ in freshly prepared $0.1 \mathrm{M}$ $\mathrm{Na}_{2} \mathrm{CO}_{3}, \mathrm{pH} 11.5$, and incubated for $30 \mathrm{~min}$ on ice. The membranes were then centrifuged at $100000 \mathrm{~g}$ for $45 \mathrm{~min}$. Bax, $\mathrm{Bcl}-2, \mathrm{Bcl}-\mathrm{x}_{\mathrm{L}}$ and cytochrome $\mathrm{c}$ oxidase in each fraction and cytochrome $c$ in cytosolic $S 100$ fraction were immunologically probed with antibodies against Bax (DAKO, Kyoto, Japan), Bcl-2 (Pharmingen), Bcl- $\mathrm{x}_{\mathrm{L}}$ (Transduction Laboratories), cytochrome $c$ oxidase (Molecular Probes, Eugene, OR, USA) and cytochrome $\mathrm{C}$ (7H8.2C12: Pharmingen), respectively.

\section{Cross-linking}

The HM fraction was resuspended in buffer $A$, and membraneimpermeable bis(sulfosuccinimidyl) suberate $\left(\mathrm{BS}^{3}\right.$; Pierce, Rockfors, IL, USA) in $5 \mathrm{mM}$ sodium citrate buffer, $\mathrm{pH}$ 5.0, was added from a 10 fold stock solution to a final concentration of $10 \mathrm{mM} .{ }^{65}$ After incubation for $30 \mathrm{~min}$ at room temperature, the cross-linker was quenched by addition of $1 \mathrm{M} \mathrm{Tris-}-\mathrm{HCl}, \mathrm{pH} 7.5$, to a final concentration of $20 \mathrm{mM}$. After quenching, membranes were lysed in RIPA buffer $(10 \mathrm{mM}$ HEPES at pH 7.5, $1 \%$ NP- $40,0.1 \%$ sodium deoxycholate, $0.1 \%$ SDS, $0.15 \mathrm{M} \mathrm{NaCl}, 1 \mathrm{mM}$ EDTA, $10 \mu \mathrm{g} / \mathrm{ml}$ aprotinin) and cleared by centrifugation at $12000 \times \mathrm{g}$. Part of this lysate was immunoprecipitated with anti-Bax monoclonal antibody (4F11: MBL, Nagoya, Japan), then size-fractionated by SDS-polyacrylamide gel electrophoresis and analyzed by immunoblot with anti-Bax polyclonal antibody (DAKO). The remainder was analyzed directly by SDSpolyacrylamide gel electrophoresis and immunoblot with anti-Bax polyclonal antibody (DAKO).

\section{Measurement of Mitochondrial $\Delta \Psi \mathrm{m}$}

Cells were incubated with $50 \mathrm{nM} \mathrm{DiOC} 6$ (3) (Molecular Probes) for $15 \mathrm{~min}$ in cultured medium at $37^{\circ} \mathrm{C}$ for measurement of $\Delta \Psi \mathrm{m}$. As a positive control for $\Delta \Psi \mathrm{m}$ loss, cells were incubated at the same time with the uncoupling agent $\mathrm{mCICCP}(50 \mu \mathrm{M})$, a protonophore, which disrupts $\Delta \Psi \mathrm{m}$. Cells were washed once with PBS, collected by centrifugation at $1000 \times \mathrm{g}$, and stored in the dark at $4^{\circ} \mathrm{C}$ prior to analysis by flow cytometry using excitation of a single $488 \mathrm{~nm}$ argon laser. Data acquisition and analysis were performed using the CellFit software. Forward scatter, perpendicular scatter and $\mathrm{DiOC}_{6}(3)$ fluorescence were measured with a $530 / 15 \mathrm{~nm}$ band pass filter. In all cases, cells were gated to exclude cellular debris associated with necrosis. At least 10000 events were collected per sample, with $\mathrm{DiOC}_{6}(3)$ fluorescence recorded as logarithmic amplified data.

\section{Caspases- 3 activity assay}

Cells were lysed in extraction buffer [50 mM piperazine-N,N'-bis(2ethanesulfonic acid) at pH 7.0,50 mM KCl, $5 \mathrm{mM} \mathrm{EGTA,} 2 \mathrm{mM} \mathrm{MgCl}_{2}$, $1 \mathrm{mM}$ DTT, $20 \mu \mathrm{M}$ cytochalasin B, $1 \mathrm{mM} \mathrm{PMSF}, 1 \mu \mathrm{g} / \mathrm{ml}$ leupeptin, $1 \mu \mathrm{g} / \mathrm{ml}$ pepstatin A, $50 \mu \mathrm{g} / \mathrm{ml}$ antipain, $10 \mu \mathrm{g} / \mathrm{ml}$ chymopain]. Crude extracts were obtained by centrifugation at $10000 \times g$ for $12 \mathrm{~min}$ at $4{ }^{\circ} \mathrm{C}$, then diluted with caspase standard buffer (100 mM HEPES, $\mathrm{pH} 7.5,10 \%$ sucrose, $0.1 \%$ 3-[(3-cholamidopropyl) dimethylammonio] propanesulfonic acid, $10 \mathrm{mM}$ DTT, $0.1 \mathrm{mg} / \mathrm{ml}$ ovalbumin), and incubated at $37^{\circ} \mathrm{C}$ for $30 \mathrm{~min}$ with $1 \mu \mathrm{M}$ fluorescent substrates, AcDEVD-MCA, to determine specific activities of caspases-3. Ac-DEVD$\mathrm{CHO}$ was added to the reaction mixture at a concentration of $5 \mu \mathrm{M}$. Levels of released 7-amino-4-methylcoumarin were measured using a spectrofluorometer with excitation at $380 \mathrm{~nm}$ and emission at $460 \mathrm{~nm}$. Excitation and emission slit width were adjusted to 10 and $20 \mathrm{~mm}$, respectively. The fluorescent substrates were custom-synthesized at the Peptides Institute, Osaka, Japan.

\section{Microscopic analysis}

Cells were fixed with $4 \%$ paraformaldehyde for 30 min after washing with ice-cold PBS and then stained with $2.5 \mu \mathrm{g} / \mathrm{ml} \mathrm{Hoechst} \mathrm{33258.} \mathrm{The}$ number of apoptotic cells was assessed by nuclei staining, and nuclei that were fragmented or condensed were scored as apoptotic. The viability of the cells was confirmed by trypan blue dye exclusion method.

\section{Note added in proof}

Since this manuscript was submitted for publication, Shimizu et al [Shimizu S, Narita M and Tsujimoto Y (1999) Bcl-2 family proteins regulate the release of apoptogenic cytochrome $c$ by the mitochondrial channel VDAC. Nature 399: 483-487] have shown that Bax and Bak stimulate opening of the voltage-dependent anion channel (VDAC) in the outer mitochondrial membrane, a mitochondrial channel through which cytochrome $c$ permeates, whereas the anti-apoptotic proteins $\mathrm{Bcl}-\mathrm{x}_{\mathrm{L}}$ closes VDAC by binding to it directly.

\section{Acknowledgements}

This work was supported in part by Grant-In-Aid for Scientific Research No. 10770701 from the Ministry of Education, Science, Sports and Culture, Japan. 


\section{References}

1. Martin SJ and Green DR (1995) Protease activation during apoptosis: death by a thousand cuts? Cell 82: $349-352$

2. Henkart PA (1996) ICE family proteases: mediators of all apoptotic cell death? Immunity 4: 195-201

3. Chinnaiyan AM and Dixit VM (1996) The cell-death machine. Curr. Biol. 6:555562

4. Alnemri ES (1997) Mammalian cell death proteases: a family of highly conserved aspartate specific cysteine proteases. J. Cell Biochem. 64: 33-42

5. Liu X, Kim CN, Yang J, Jemmerson R and Wang X (1996) Induction of apoptotic program in cell-free extracts: requirement for dATP and cytochrome c. Cell 86: $147-157$

6. Vaux DL (1997) CED-4-the third horseman of apoptosis. Cell 90: 389-390

7. Zou H, Henzel WJ, Liu X, Lutschg A and Wang X (1997) Apaf-1, a human protein homologous to $\mathrm{C}$. elegans CED-4, participates in cytochrome c-dependent activation of caspase-3. Cell 90: 405-413

8. Li P, Nijhawan D, Budihardjo I, Srinivasula SM, Ahmad M, Alnemri ES and Wang X (1997) Cytochrome $c$ and dATP-dependent formation of Apaf-1/caspase-9 complex initiates an apoptotic protease cascade. Cell 91: 479-489

9. Pan G, Humke EW and Dixit VM (1998) Activation of caspases triggered by cytochrome $\mathrm{c}$ in vitro. FEBS Letts. 426: 151-154

10. Ikemoto H, Tani E, Matsumoto T, Nakano A and Furuyama J (1995) Apoptosis of human glioma cells in response to calphostin $\mathrm{C}$, a specific protein kinase $\mathrm{C}$ inhibitor. J. Neurosurg. 83: 1008-1016

11. Ozaki I, Tani E, Ikemoto H, Kitagawa $H$ and Fujikawa $H$ (1999) Activation of stress-activated protein kinase/c-jun $\mathrm{NH}$ 2-terminal kinase and p38 kinase in calphostin C-induced apoptosis requires caspase-3-like proteases but dispensable for cell death. J. Biol. Chem. 274: 5310-5317

12. Kobayashi E, Nakano H, Morimoto M and Tamaoki T (1989) Calphostin C (UCN$1028 \mathrm{C}$ ), a novel microbial compound, is a highly potent and specific inhibitor of protein kinase C. Biochem. Biophys. Res. Commun. 159: 548-553

13. Oltvai ZN, Milliman CL and Korsmeyer SJ (1993) Bcl-2 heterodimerizes in vivo with a conserved homolog, Bax, that accelerates programmed cell death. Cell 74: $609-619$

14. Yin X-M, Oltvai ZN and Korsmeyer S (1994) BH1 and BH2 domains of Bcl-2 are required for inhibition of apoptosis and heterodimerization with Bax. Nature 369 : $321-323$

15. Wolter KG, Hsu YT, Smith CL, Nechushtan A and Xi XG (1997) Movement of Bax from the cytosol to mitochondria during apoptosis. J. Cell Biol. 139: 1281-1292

16. Manon S, Chaudhuri B and Guérin M (1997) Release of cytochrome c and decrease of cytochrome coxidase in Bax-expressing yeast cells, and prevention of these effects by coexpression of Bcl-xL. FEBS Letts. 415: 29-32

17. Knudson CM and Korsmeyer SJ (1997) Bcl-2 and Bax function independently to regulate cell death. Nat. Genet. 16: 358-363

18. Xiang J, Chao DT and Korsmeyer SJ (1996) BAX-induced cell death may not require interleukin 1 beta-converting enzyme-like proteases. Proc. Natl. Acad. Sci. USA 93: $14559-14563$

19. Hsu YT, Wolter KG and Youle RJ (1997) Cytosol-to-membrane redistribution of Bax and Bcl-xL during apoptosis. Proc. Natl. Acad. Sci. USA 94: 3668-3672

20. Goping IS, Gross A, Lavoie JN, Nguyen M, Jemmerson R, Roth K, Korsmeyer SJ and Shore GC (1998) Regulated targeting of BAX to mitochondria. J. Cell Biol. 143: $207-215$

21. Gross A, Jockel J, Wei MC and Korsmeyer SJ (1998) Enforced dimerization of Bax results in its translocation, mitochondrial dysfunction and apoptosis. EMBO J. 17: $3878-3885$

22. Zhang H, Heim J and Meyhack B (1998) Redistribution of Bax from cytosol to membranes is induced by apoptotic stimuli and is an early step in the apoptotic pathway. Biochem. Biophys. Res. Commun. 251: 454-459

23. Rossé T, Olivier R, Monney L, Rager M, Conus S, Fellay I, Jansen Band Borner C (1998) Bcl-2 prolongs cell survival after Bax-induced release of cytochrome C. Nature 391: $496-499$

24. Finucane DM, Bossy-Wetzel E, Waterhouse NJ, Cotter TG and Green DR(1999) Bax-induced caspase activation and apoptosis via cytochrome $c$ release from mitochondria is inhibitable by Bcl-xL. J. Biol. Chem. 274: 2225-2233

25. JürgensmeierJM, Xie Z, Deveraux Q, Ellerby L, Bredesen D and Reed JC (1998) Bax directly induces release of cytochrome $\mathrm{c}$ from isolated mitochondria. Proc. Natl. Acad. Sci. USA 95: 4997-5002
26. Eskes R, Antosson B, Osen-Sand A, Montessuit S, Richter C, Sadoul R, Mazze G, Nichols A and Martinou J-C (1998) Bax-induced cytochrome c release from mitochondria is independent of the permeability transition pore but highly dependent on Mg2+ ions. J. Cell Biol. 143: 217-224

27. Yang J, Liu X, Bhalla K, Kim CN, Ibrado AM, Cai J, Peng TI, Jones DP and Wang X (1997) Prevention of apoptosis by Bcl-2: release of cytochrome $\mathrm{C}$ from mitochondria blocked. Science 275: $1129-1132$

28. Kluck RM, Bossy-Wetzel E, Green DR and Newmeyer DD (1997) The release of cytochrome c from mitochondria: a primary site for $\mathrm{Bcl}-2$ regulation of apoptosis. Science 275: $1132-1136$

29. Duckett CS, Li F, Wang Y, Tomaselli KJ, Thompson CB and Armstrong RG (1998) Human IAP-like protein regulates programmed cell death downstream of Bcl-xL and cytochrome c. Mol. Cell Biol. 18: 608-615

30. Kantrow SP and Piantadosi CA (1997) Release of cytochrome c from liver mitochondria during permeability transition. Biochem. Biophys. Res. Commun. 232: $669-671$

31. Pastorino JG, Chen ST, Tafani M, Snyder JW and Farber JL (1998) The overexpression of Bax produces cell death upon induction of the mitochondrial permeability transition. J. Biol. Chem. 273: 7770-7775

32. Zamzami N, Marchetti P, Castedo M, Zamin C, Vayssiere JL, Petit PX and Kroemer G (1995) Reduction in mitochondrial potential constitutes an early irreversible step of programmed lymphocyte death in vivo. J. Exp. Med. 181: $1661-1672$

33. Zamzami N, Marchetti P, Castedo M, Decaudin D, Macho A, Hirsch T, Susin SA PetitPX, Mignotte B and Kroemer G (1995) Sequential reduction of mitochondrial transmembrane potential and generation of reactive oxygen species in early programmed cell death. J. Exp. Med. 182: $367-377$

34. Zoratti M and Szabo I (1995) The mitochondrial permeability transition. Biochim. Biophys. Acta 1241: 139-176

35. Marchetti P, Castedo M, Susin SA, Zamzami N, Hirsch T, Macho A, Haeffner A Hirsch F, Geuskens M and Kroemer G (1996) Mitochondrial permeability transition is a central coordinating event of apoptosis. J. Exp. Med. 184: 11551160

36. Bossy-WetzelE, NewmeyerDD and GreenDR(1998) Mitochondrial cytochrome c release in apoptosis occurs upstream of DEVD-specific caspase activation and independently of mitochondrial transmembrane depolarization. EMBO J. 17: $37-49$

37. Nguyen M, MillarDG, Yong VW, Korsmeyer SJ and Shore GC (1993) Targeting of $\mathrm{Bcl}-2$ to the mitochondrial outer membrane by a $\mathrm{COOH}$-terminal signal anchor sequence. J. Biol. Chem. 268: 25265-25268

38. Nguyen M, Branton PE, Walton PA, Oltavai ZN, Korsmeyer SJ and Shore GC (1994) Role of membrane anchor domain of Bcl-2 in suppression of apoptosis caused by E1B-defective adenovirus. J. Biol. Chem. 269: 16521-16524

39. Fujiki Y, Fowler S, Shio H, Hubbard AL and Lazarow P (1982) Polypeptide and phospholipid composition of the membrane of rat liver peroxisomes: comparison with endoplasmic reticulum and mitochondrial membranes. J. Cell Biol. 93: 103110

40. Hsu YT and Youle RJ (1997) Nonionic detergents induce dimerization among members of the Bcl-2 family. J. Biol. Chem. 272: 13829-13834

41. Krebs JF, Armstrong RC, Srinivasan A, Aja T, Wong AM, Aboy A, Sayers R, Pham B, Vu T, Hoang K, Karanewsky DS, Leist C, Schmitz A, Wu JC, Tomaselli KJ and Fritz LC (1999) Activation of membrane-associated procaspase-3 is regulated by $\mathrm{Bcl}-2$. J. Cell Biol. 144: $915-926$

42. Tzagoloff A (1970) Assembly of the mitochondrial membrane system. 3. Function and synthesis of the oligomycin sensitivity - conferring protein of yeast mitochondria. J. Biol. Chem. 245: 1545-1551

43. Deveraux Q, Takahashi R, Salvesen GS and Reed JC (1997) X-linked IAP is a direct inhibitor of cell death proteases. Nature 388: $300-303$

44. Matsuyama S, Xu Q, Velours J and Reed JC (1998) The mitochondrial $F_{0} F_{1}$. ATPase proton pump is required for function of the proapoptotic protein Bax in yeast and mammalian cells. Mol. Cell 1: $327-336$

45. Deckwerth TL, Elliott JL, Knudson CM, Johnson EM Jr., Snider WD and Korsmeyer SJ (1996) BAX is required for neuronal death after trophic factor deprivation and during development. Neuron 17: 401-411 
46. Sakakura C, Sweeney EA, Shirahama T, Igarashi $Y$, Hakomori S, Nakatani $H$ Tsujimoto H, Imanishi T, Ohgaki M, Ohyama T, Yamazaki J, Hagiwara A Yamaguchi T, Sawai Kand Takahashi T (1996) Overexpression of baxsensitizes human breast cancer MCF-7 cells to radiation-induced apoptosis. Int. J. Cancer 67: $101-105$

47. Han J, Sabbatini P, Perez D, Rao L, Modha D and White E (1996) The E1B 19K protein blocks apoptosis by interacting with the inhibiting the p53-inducible and death-promoting Bax protein. Genes Dev. 16: 461-477

48. Zha H, Fisk HA, Yaffe N, Mahajan N, Herman B and Reed JC (1996) Structurefunction comparisons of the proapoptotic protein Bax in yeast and mammalian cells. Mol. Cell Biol. 16: 6494-6508

49. Hsu YT and Youle RJ (1998) Bax in murine thymus is a soluble monomeric protein that displays differential detergent-induced conformation. J. Biol. Chem. 273: $10777-10783$

50. Narita M, Shimizu S, Ito T, Chittenden T, Lutz RJ, Matsuda H and Tsujimoto $Y$ (1998) Bax interacts with the permeability transition pore to induce permeability transition and cytochrome $c$ release in isolated mitochondria. Proc. Natl. Acad. Sci. USA 95: $14681-14686$

51. Vander Heiden MG, Chandel NS, Williamson EK, Schumacker PT and Thompson CB (1997) Bcl-xL regulates the membrane potential and volume homeostasis of mitochondria. Cell 91: 627-637

52. Marzo I, Brenner C, Zamzami N, Jürgensmeier JM, Susin SA, Vieira LA, Prévost M-C, Xie Z, Matsuyama S, Reed JC and Kroemer G (1998) Bax and adenine nucleotide translocator cooperate in the mitochondrial control of apoptosis. Science 281: 2027-2031

53. Bernardi P, Broekemeier KM and Pfeiffer DR (1994) Recent progress on regulation of the mitochondrial permeability transition pore: a cyclosporinsensitive pore in the inner mitochondrial membrane. J. Bioenerg. Biomembr. 26 : $509-517$

54. Ichas F, Jouaville LS and Mazat J-P (1997) Mitochondria are excitable organelles capable of generating and conveying electrical and calcium signals. Cell 89: 1145-1153

55. Simonian PL, Grillot DAM, Merino R and Nunez G (1996) Bax can antagonize $\mathrm{Bcl}-\mathrm{xL}$ during etoposide and cisplatin-induced cell death independently of its heterodimerization with Bcl-xL. J. Biol. Chem. 271: 22764-22772
56. Zha H and Reed JC (1997) Heterodimerization-independent functions of cell death regulatory proteins Bax and Bcl-2 in yeast and mammalian cells. J. Biol. Chem. 272: 31482-31488

57. Wang K, Gross A, Waksman G and Korsmeyer SJ (1998) Mutagenesis of the $\mathrm{BH} 3$ domain of $\mathrm{BAX}$ identifies critical residues for dimerization and killing. Mol. Cell Biol. 18: 6083-6089

58. Antonsson B, Conti F, Ciavatta A, Montessuit S, Lewis S, Martinou I, Bernasconi L, Bernard A, Mermod JJ, Mazzei G, Maundrell K, Gambale F, Sadoul R and Martinou JC (1997) Inhibition of Bax channel-forming activity by Bcl-2. Science 277: $370-372$

59. Minn AJ, Vélez P, Schendel SL, Liang H, Muchmore SW, Fesik SW, Fill M and Thompson CB (1997) Bcl-xL forms an ion channel in synthetic lipid membranes. Nature 385: 353-357

60. Schlesinger P, Gross A, Yin XM, Yamamoto K, Saito M, Waksman G and Korsmeyer $S$ (1997) Comparison of the ion channel characteristics of proapoptotic Bax and antiapoptotic BCL-2. Proc. Natl. Acad. Sci. USA 94: $11357-11362$

61. Schendel SL, Montal M and Reed JC (1998) Bcl-2 family protein as ion-channels. Cell Death Differ. 5: 372-380

62. Matsuyama S, Schendel SL, Xie Z and Reed JC (1998) Cytoprotection by Bcl-2 requires the pore-forming $\alpha 5$ and $\alpha 6$ helices. J. Biol. Chem. 273: 30995-31001 membranes is induced by apoptotic stimuli and is an early step in the apoptotic pathway. Biochem. Biophys. Res. Commun. 251: 454-459

63. Aritomi M, Kunishima N, Inohara N, Ishibashi Y, Ohta S and Morikawa K (1997) Crystal structure of rat Bcl-xL. Implications for the function of the Bcl-2 protein family. J. Biol. Chem. 272: 27886-27892

64. Ishibashi Y, NishimakiK, Asoh S, Nanbu-Wakao R, Yamada T and Ohta S (1998) Pore formation domain of human pro-apoptotic Bax induces mammalian apoptosis as well as bacterial death without antagonizing anti-apoptotic factors. Biochem. Biophys. Res. Commun. 243: 609-616

65. Partis MD, Griffiths DG, Roberts GC and Beechey RB (1983) Cross-linking of protein by $\omega$-maleimido alkanoyl N-hydroxysuccinimido esters. J. Protein Chem. 2: $263-277$ 